\title{
A study on the effects of human resources management on employee performance
}

\author{
Mohamad Malekmohamadi Faradonbeh ${ }^{a^{*}}$, Sahar Biglaria ${ }^{\text {a }}$ Mohammad Reza Shirvani ${ }^{\mathrm{b}}$, Farimah \\ Behzadian $^{a}$ and Fatemeh Malekmohammadi Faradonbeh ${ }^{\mathrm{a}}$
}

${ }^{a}$ Department of Public Administration, Islamic Azad University, Dehaghan Branch, Esfahan, Iran

${ }^{b}$ Department of Public Administration, Islamic Azad University, Khorasgan Branch, Esfahan, Iran

\section{H R O N I C L E A B S T R A C T}

Article history:

Received February 28, 2014

Received in revised format

19 March 2014

Accepted 20 March 2014

Available online

March 262014

Keywords:

Employee performance

Human resources management

Social security

\begin{abstract}
This paper presents an empirical investigation to study the effect of human resources management on employee performance in one of Iranian social security organizations. The proposed study designs a questionnaire for human resources management with 23 questions consists of five components including Beneficiary groups, Long-term achievements, Situational factors, Human resources achievements and human resources achievement for measuring human resources management figures. In addition, the study uses another questionnaire consists of 37 questions for measuring organizational performance. Cronbach alpha for human resources management and organizational performance are calculated as 0.885 and 0.873 , respectively. Using Pearson correlation ratio as well as stepwise regression technique, the study detects a positive and meaningful relationship between human resources management and organizational performance.
\end{abstract}

\section{Introduction}

During the past few years, there have been several studies to learn more about the relationship between human resources management (HRM) and employee performance (Tyson, 1987; Delery, 1998; Wright, \& McMahan, 1992; Basu, 2001; Martocchio \& Joe, 2004; Mullins, 2007; Rezaei et al., 2011). Strategic HRM researchers have strongly defended a system perspective and have given some evidence that certain systems of human resource practices influence on individual and organizational performance. Jiang et al. (2012) reviewed the components of human resource systems and described how the parts of human resource systems work together to impact employee performance.

*Corresponding author. Tel: +989133809866

E-mail addresses: sajadmalek68@yahoo.com (M. Malekmohamadi Faradonbeh) 
Kuzu and Özilhan (2014) investigated the effect of employee relationships and knowledge sharing on employees' performance in hotels by surveying on a five star hotel and confirmed the effects of knowledge sharing on employee's performance. There are some evidences to believe that training, rewards and empowering employees as an indication of high-performance work practices could influence on the performance of employees. According to Karatepe (2013), high-performance work practices and hotel employee performance could be considered as the mediation of work engagement. They stated that work engagement could maintain a stronger relationship with extra-role customer service than with job performance. In addition, he reported that work engagement could act as a full mediator of the impacts of high-performance work practices on job performance and extra-role customer service.

Güngör (2011) investigated the relationship between the reward management system applications and employee performance of selected bank employees in Istanbul. The study concentrated on the role of motivation as an intervening factor. They stated that organizations implementation reward systems and strategies could motivate their employees and increase their performance. In this study, employee performance effectiveness was determined on reward systems.

Buller and McEvoy (2012) identified important linkages between the firm's strategy, its human resources, and performance outcomes. They first reviewed the relevant literature concentrating on the role of human resources in building competitive advantage. They then presented a multi-level model describing how human resource management practices could effectively align organizational, group and individual factors with the organization's strategy.

Santiago and Alcorta (2012) studied the impact of HRM practices on the likelihood that a firm performs in-house research and development, which is broadly interpreted as learning and an appropriate mechanism promoting absorptive capacity and supporting technology capability-building. Many firms are able to choose between two learning strategies by either exploiting existing knowledge, or performing complex explorations to acquire new knowledge. Various knowledge requirements are normally associated with distinct of research and development outcomes. Truss and Gratton (1994) investigated conceptual issues related to strategic human resource management (SHRM) and explored some of the broader issues related to SHRM. They highlighted the key variables and interrelationships, which are necessary in a model of SHRM, and presented a more detailed critical analysis of the contribution of the literature in each of these components. Rogers and Wright (1998) measured organizational performance in strategic human resource management by exploring issues with performance information markets.

\section{The proposed study}

This paper presents an empirical investigation to study the effect of human resources management on employee performance in one of Iranian social security organizations. The proposed study designs a questionnaire for human resources management with 23 questions consists of five components including Beneficiary groups (Konrad \& Linnehan, 1995; Grover \& Crooker, 1995), Long-term achievements (Paauwe, 2004), Situational factors, Human resources achievements and human resources strategies (Truss \& Gratton, 1994; Boxall \& Purcell, 2003) for measuring human resources management figures. In addition, the study uses another questionnaire consists of 37 questions for measuring organizational performance. The proposed study determines the sample size as follows,

$$
n=\frac{N \times z_{\alpha / 2}^{2} \times p \times q}{\varepsilon^{2} \times(N-1)+z_{\alpha / 2}^{2} \times p \times q},
$$


where $N$ is the population size, $p=1-q$ represents the yes/no categories, $z_{\alpha / 2}$ is CDF of normal distribution and finally $\varepsilon$ is the error term. Since we have $p=0.5, z_{\alpha / 2}=1.96$ and $N=110$, the number of sample size is calculated as $n=61$. Cronbach alpha for human resources management and organizational performance are calculated as 0.885 and 0.873 , respectively, which are well above the minimum acceptable limit of 0.70 . Table 1 demonstrates some basic statistics associated with the propsoed study.

\section{Table 1}

The summary of some basic statistics

\begin{tabular}{lcc}
\hline Variable & Mean & Standard deviation \\
\hline Beneficiary groups & 3.29 & 0.83 \\
Long-term achievements & 3.25 & 0.72 \\
Situational factors & 3.35 & 0.61 \\
Human resources achievements & 3.57 & 0.63 \\
Human resources strategies & 3.50 & 0.69 \\
Human resources management & 3.39 & 0.56 \\
Employee performance & 2.05 & 0.27 \\
\hline
\end{tabular}

In order to perform some statistical tests we need to find out whether the data are normally distributed or not. Table 2 demonstrates the results of Kolmogorov-Smirnove test.

Table 2

The summary of Kolmogorov-Smirnove test

\begin{tabular}{lcc}
\hline Variable & K-S & Sig. \\
\hline Beneficiary groups & 1.17 & 0.128 \\
Long-term achievements & 1.15 & 0.142 \\
Situational factors & 1.22 & 0.122 \\
Human resources achievements & 0.878 & 0.424 \\
Human resources strategies & 1.307 & 0.066 \\
Human resources management & 0.999 & 0.271 \\
Employee performance & 1.308 & 0.065 \\
\hline
\end{tabular}

The results of Table 2 indicate that all components of the survey are normally distributed when the level of significance is five percent. This means we may use Pearson correlation ratio as well as stepwise regression technique to study the relationship between human resources management and employee performance in social security organization.

\section{The results}

In this section, we present details of the implementation of Pearson correlation ratio as well as stepwise regression technique to examine the hypotheses of the survey.

\subsection{Pearson correlation}

The first step to examine the relationship between human resources management and employee performance is to look at Pearson correlation test. In our survey, this ratio has been determined as $\mathrm{r}=$ 0.646 with Sig. $=0.000$. This means there is a positive and meaningful relationship between these two components when the level of significance is one percent. In addition, the Pearson correlation ratios for various components of human resources management are measured and Table 3 demonstrates the results of our survey. 


\section{Table 3}

The summary of Pearson correlation ratio between various components of human resources management and employee performance

\begin{tabular}{lcc}
\hline Variable & Pearson correlation & Sig. \\
\hline Beneficiary groups & 0.692 & 0.000 \\
Long-term achievements & 0.519 & 0.000 \\
Situational factors & 0.532 & 0.000 \\
Human resources achievements & 0.412 & 0.002 \\
Human resources strategies & 0.378 & 0.007 \\
\hline
\end{tabular}

The results of Table 3 clearly specify that all components of human resources management influence on employee performance, positively.

\subsection{Stepwise regression technique}

In order to examine the effects of various components of the human resources management on employee performance, the study uses stepwise regression technique and Table 4 demonstrates the summary of our findings.

\section{Table 4}

The summary of stepwise regression technique

\begin{tabular}{lccc}
\hline Variable & Pearson correlation & t-value & Sig. \\
\hline Intercept & 0.693 & 5.942 & 0.000 \\
Beneficiary groups & 0.181 & 3.256 & 0.002 \\
Long-term achievements & 0.133 & 3.09 & 0.000 \\
Situational factors & 0.176 & 7.98 & 0.000 \\
Human resources achievements & 0.109 & 2.10 & 0.013 \\
Human resources strategies & 0.094 & 2.15 & 0.017 \\
\hline
\end{tabular}

According to the results of Table 4, all components of human resources management influence on employee performance, positively. In our survey, beneficiary groups maintain the highest impact followed by situational factors, long-term achievement, human resources achievements and human resources strategies. Note that R-Square is equal to 0.503 , which means the regression technique could describe approximately $50 \%$ of the changes between dependent variable, employee performance and HRM independent variables. In addition, F-value is equal to 8.88 with P-value $=$ 0.000 , which means the model represents a meaningful relationship between independent and dependent variables.

\section{Conclusion}

In this paper, we have presented an empirical investigation to study the effects of human resources management on employee performance in one of Iranian social security organizations. The proposed study has implemented Pearson correlation ratio as well as stepwise regression technique to examine the relationship between these two variables and the results of our survey have confirmed that there were positive and meaningful relationships between all components of human resources management and employee performance. The results of this study are consistent with findings of Chadwick and Cappelli (1999), Mullins (2007), Busi and Bititci (2006), McGuire (2006) and Santiago and Alcorta (2012). 


\section{Acknowledgement}

The authors would like to thank the anonymous referees for constructive comments on earlier version of this paper.

\section{References}

Boxall, P., \& Purcell, J. (2003). Strategy and human resource management. Industrial \& Labor Relations Review, 57(1), 84.

Buller, P. F., \& McEvoy, G. M. (2012). Strategy, human resource management and performance: Sharpening line of sight. Human Resource Management Review, 22(1), 43-56.

Busi, M., \& Bititci, U. S. (2006). Collaborative performance management: present gaps and future research. International Journal of Productivity and Performance Management, 55(1), 7-25.

Basu, R. (2001). New criteria of performance management: a transition from enterprise to collaborative supply chain. Measuring Business Excellence, 5(4), 7-12.

Chadwick, C., \& Cappelli, P. (1999). Alternatives to generic strategy typologies in strategic human resource management. Research in personnel and human resources management, Supplement, 4, 11-29.

Delery, J. E. (1998). Issues of fit in strategic human resource management: Implications for research. Human Resource Management Review, 8(3), 289-309.

Grover, S. L., \& Crooker, K. J. (1995). Who appreciates family-responsive human resource policies: The impact of family-friendly policies on the organizational attachment of parents and nonparents. Personnel psychology,48(2), 271-288.

Güngör, P. (2011). The relationship between reward management system and employee performance with the mediating role of motivation: A quantitative study on global banks. Procedia - Social and Behavioral Sciences, 24, 1510-1520.

Jiang, K., Lepak, D. P., Han, K., Hong, Y., Kim, A., \& Winkler, A. L. (2012). Clarifying the construct of human resource systems: Relating human resource management to employee performance. Human Resource Management Review, 22(2), 73-85.

Karatepe, O.M. (2013). High-performance work practices and hotel employee performance: The mediation of work engagement. International Journal of Hospitality Management, 32, 132-140.

Konrad, A. M., \& Linnehan, F. (1995). Formalized HRM structures: Coordinating equal employment opportunity or concealing organizational practices?. Academy of Management Journal, 38(3), 787 820.

Kuzu, Ö. H., \& Özilhan, D. (2014). The effect of employee relationships and knowledge sharing on employees' performance: An empirical research on service industry. Procedia-Social and Behavioral Sciences, 109, 1370-1374.

McGuire, M. (2006). Collaborative public management: Assessing what we know and how we know it. Public Administration Review, 66(s1), 33-43.

Martocchio, J. J., \& Joe, M. (2004). Strategic compensation: A human resource management approach. Pearson Education India.

Mullins, L. J. (2007). Management and organisational behaviour. Pearson Education.

Paauwe, J. (2004). HRM and performance: Achieving long-term viability. Oxford University Press.

Rezaei, A.R., Çelik, T., \& Baalousha, Y. (2011). Performance measurement in a quality management system. Scientia Iranica, 18(3), 742-752.

Rogers, E. W., \& Wright, P. M. (1998). Measuring organizational performance in strategic human resource management: Problems, prospects and performance information markets. Human Resource Management Review, 8(3), 311-331.

Santiago, F., \& Alcorta, L. (2012). Human resource management for learning through knowledge exploitation and knowledge exploration: Pharmaceuticals in Mexico. Structural Change and Economic Dynamics, 23(4), 530-546. 
Truss, C., \& Gratton, L. (1994). Strategic human resource management: A conceptual approach. International Journal of Human Resource Management,5(3), 663-686.

Tyson, S. (1987). The management of the personnel function. Journal of Management Studies, 24(5), 523-532.

Wright, P. M., \& McMahan, G. C. (1992). Theoretical perspectives for strategic human resource management. Journal of Management, 18(2), 295-320. 